\title{
Severe Hemorrhage Induced Expressions of Ferritin and Heme Oxygenase-1 in Leukocytes
}

Jung Wan Kwon and Yoon-yub Park*

Department of Physiology, School of Medicine, Catholic University of Daegu, Daegu 705-718, Korea

Received May 15, 2009 / Accepted May 21, 2009

\begin{abstract}
Serum ferritin levels are elevated in subjects with acute lung injury (ALI), and abnormalities in plasma and lung iron chemistry have also been demonstrated in ALI and acute respiratory distress syndrome (ARDS). Stress-inducible heme oxygenase-1 (HO-1), as well as ferritin, had shown anti-inflammatory actions. Biomarkers for early detection in patients who are likely to develop ARDS would give several therapeutic chances to the patients. In order to verify the predictability in severe hemorrhage-induced ALI in rats, we measured serum ferritin and HO-1 concentrations before and after hemorrhage. Severe hemorrhages significantly increased the number of leukocytes in bronchoalveolar lavage (BAL) fluid and lung tissue myeloperoxidase activity. Both serum ferritin and HO-1 levels increased following hemorrhage, but ferritin levels were elevated earlier than HO-1. In BAL cell immunohistochemical studies, ferritin and HO-1 expressions increased after hemorrhage and localized in the cytoplasm of leukocytes. These findings suggest that inflammatory leukocytes in BAL fluid can secrete ferritin and HO-1, and serum ferritin levels might be more valid factor in predicting ARDS than HO-1 levels in hemorrhage-induced ALI.
\end{abstract}

Key words : Acute lung injury, ferritin, heme oxygenase-1, hemorrhage

\section{Introduction}

The pathogenesis of acute lung injury (ALI) and acute respiratory distress syndrome (ARDS) appears to involve imbalance between oxidants and antioxidants [5,19,32]. Abnormalities in plasma and lung iron chemistry also have been demonstrated in ALI and ARDS [5,13,14]. Iron is a key biological catalyst for oxygen utilization but can also generate reactive oxygen species (ROS). Previous studies have shown the potential for proinflammatory and/or directly injurious roles of iron in the setting of ALI [5,12,22,31]. These findings suggest that abnormal iron regulation may contribute to the pathogenesis of ALI.

Heme oxygenase-1 (HO-1), an inducible form of $\mathrm{HO}$, is a $32-\mathrm{kD}$ heat shock protein expressed in response to various noxious stimuli including heavy metals, hyperoxia, hypoxia, endotoxin, hydrogen peroxide, and inflammatory cytokines [23,25]. Several results suggest that increased expression of HO-1 can protect the host from various pathological conditions. $\mathrm{HO}$ catalyzes the conversion of heme into $\mathrm{CO}, \mathrm{Fe}^{2+}$, and biliverdin $[23,25,38]$. Ferrous iron $\left(\mathrm{Fe}^{2+}\right)$ induces the expression of ferritin, a multimeric iron-chelating

\footnotetext{
*Corresponding author

Tel : +82-53-650-4475, Fax : +82-53-621-4106

E-mail : yypark@cu.ac.kr
}

protein [2]. Ferritin synthesis has been shown to increase cell resistance to oxidative stress by sequestering intracellular catalytic iron $[10,11]$ although variable causes can lead to elevate ferritin.

In ARDS, it has been known that HO-1 concentration in bronchoalveolar lavage (BAL) fluid is correlated positively with changes in BAL fluid ferritin concentration [7]. Serum ferritin levels are increased in patients with ALI and multiple organ failure [9,34], and severe hemorrhage and intestinal ischemia/reperfusion induced ALI increase serum and BAL ferritin levels in rats [27-30]. However, Park et al. [28] reported that there was no close relationship between serum and BAL ferritin increases, therefore, the mechanisms responsible for the increase of serum and BAL ferritin and their relationship to ALI are still unclear. Early and accurate identification of patients who are likely to develop ARDS would give several therapeutic chances to the patients. Development of specific disease marker(s), therefore, for predicting ARDS is a desirable goal for researchers [8].

Therefore, this investigation deals with the pathophysiological relationship between the changes of ferritin and HO-1 levels in severe hemorrhage-induced ALI. In addition, it is worthy to evaluate the changes of serum ferritin and HO-1 concentrations as a biological marker for the early detection of ARDS. 


\section{Materials and Methods}

Experimental protocols were approved by the Ethical Committee of Animal Experiments in Daegu Catholic University, School of Medicine. Adult male Sprague-Dawley rats weighing approximately 300-450 $\mathrm{g}$ were used in this study. Rats were anesthetized by an intraperitoneal injection of ketamine $(80 \mathrm{mg} / \mathrm{kg})$ and xylazine $(16 \mathrm{mg} / \mathrm{kg})$.

Rats were randomly divided into two groups and were given an intraperitoneal injection of saline vehicle $(3 \mathrm{ml} / \mathrm{kg})$ or $\mathrm{PLA}_{2}$ inhibitor mepacrine $(60 \mathrm{mg} / \mathrm{kg})$. Left femoral artery was then incised and polyethylene catheter (PE-50, Clay-Adams, Sparks, MD, USA) filled with heparinized saline $(100 \mathrm{U} / \mathrm{ml})$ were inserted into each femoral artery for blood removal (hemorrhage) and blood sampling. Thirty minutes after injection of saline or mepacrine, arterial blood was withdrawn from the catheter into a syringe at a constant rate of $4 \mathrm{ml} / \mathrm{kg} / \mathrm{min}$ for 5 minutes (total $20 \mathrm{ml} / \mathrm{kg}$ ) using a withdrawal pump (Model 22, Harvard Apparatus, Holliston, MA, USA). Sham rats were anesthetized and catheterized similarly but were not hemorrhaged. All the rats were not resuscitated after hemorrhage. For measurement of serum ferritin, HO-1, and protein concentrations, $200 \mu \mathrm{l}$ of arterial blood was collected through the femoral arterial catheter before hemorrhage and every $30 \mathrm{~min}$ thereafter. The rats remained deeply anesthetized through the entire experiment.

Bronchoalveolar lavage was performed by cannulating the trachea and instilling $8.0 \mathrm{ml}$ of cold normal saline with a syringe. Saline was flushed three times. Approximately 6 $\mathrm{ml}$ of lavage fluid was recovered from each rat. Then the fluid was centrifuged at $1,000 \times g$ for $10 \mathrm{~min}$, and the resultant cell-free supernatant collected and stored at $-70^{\circ} \mathrm{C}$ for additional assays. The cell pellet was resuspended with 1.0 $\mathrm{ml}$ of distilled water and $1.0 \mathrm{ml}$ of Hanks' balanced salt solution for a few seconds and centrifuged again. After the supernatant was discarded, the pellet was suspended in 0.2 $\mathrm{ml}$ of normal saline. Total leukocytes were counted with a hemocytometer.

To compare the relationship between the changes of ferritin and HO-1 in serum and BAL fluid, immunochemistry of BAL leukocytes were performed. After counting the leukocyte numbers in BAL fluid, remaining cells were attached to the glass slides by cytospin preparation. Slides were air-dried and stored at $-70^{\circ} \mathrm{C}$ until staining. Frozen slides were brought to room temperature and fixed in $2 \%$ paraf- ormaldehyde for $30 \mathrm{~min}$. Cells were permeabilized with $0.1 \%$ triton-X in PBS for $30 \mathrm{~min}$. The slides were blocked in 5\% normal goat serum in PBS and were incubated with the primary antibody to ferritin (DAKO, Carpenteria, CA, USA) at 1:100 dilutions or HO-1 (Santa Cruz Biotechnology, Inc., Santa Cruz, CA, USA) at 1:20 dilutions in PBS. They were washed 5 times ( 5 min each) and incubated with the secondary antibody, Cy3-conjugated donkey anti-rabbit IgG (Jackson Immunoresearch Laboratories, West Grove, PA, USA), at a dilution of 1:150 in PBS for $1 \mathrm{hr}$ and added DAPI $(5 \mu \mathrm{l} / \mathrm{ml})$ or propidium iodide $(10 \mu \mathrm{g} / \mathrm{ml})$ to stain nuclei or nucleic acids. The slides were washed 6 times and put in the moist chamber box overnight with PBS.

For the confirmation of pulmonary leukocyte infiltration, whole lungs were collected and frozen at $-70^{\circ} \mathrm{C}$ for analysis of myeloperoxidase (MPO) activity. Lung MPO activity was measured by previously described method [17]. Briefly, frozen lungs were thawed and then homogenized in $4 \mathrm{ml}$ of $20 \mathrm{mM}$ potassium phosphate buffer $(\mathrm{pH} 7.4)$, and centrifuged at $30,000 \times \mathrm{g}$ for $30 \mathrm{~min}$ at $4^{\circ} \mathrm{C}$. The pellet was resuspended in $4 \mathrm{ml}$ of $50 \mathrm{mM}$ potassium phosphate buffer ( $\mathrm{pH}$ 6.0) containing $0.5 \%$ hexadecyltrimethylammonium bromide, sonicated for $90 \mathrm{sec}$, and incubated for $2 \mathrm{hr}$ at $60^{\circ} \mathrm{C}$. Then MPO activity was determined using o-dianisidine as the substrate and $\mathrm{H}_{2} \mathrm{O}_{2}$ to initiate the reaction.

Serum protein concentrations were measured using a bicinchoninic acid method (Sigma, St. Louis, MO, USA). Ferritin and HO-1 concentrations were quantified with commercially available ELISA kit specific for rat ferritin (Panapharm Laboratories, Kumamoto, Japan) and HO-1 (Takara Bio Inc., Shiga, Japan) following the instructions.

All data are presented in means \pm SEM. Unpaired $t$-test was used to make comparison between groups, and paired t-test was used for paired observations within a group. A $p$ value of $<0.05$ was considered statistically significant.

\section{Results}

\section{Effects of hemorrhage on lung inflammation}

Acute lung injury was induced in rats by means of severe hemorrhage. The BAL fluid leukocyte number and lung MPO activity were significantly increased by hemorrhage compared to the values obtained from sham rats (Fig. 1 \& 2). Mepacrine treatment had significantly decreased these parameters compared to untreated hemorrhaged. Mepacrine per se did not affect these parameters (data not shown). 


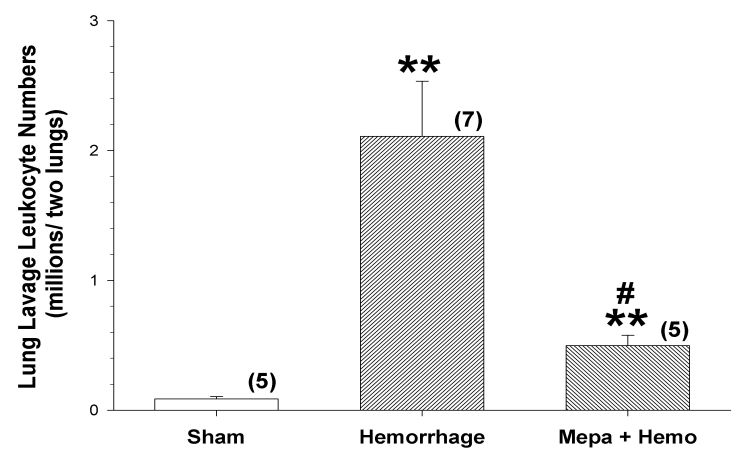

Fig. 1. Severe hemorrhage significantly increased number of leukocyte in lung lavage fluid. Mepacrine pretreatment (Mepa+Hemo) effectively suppressed the increase. The data shown are means \pm SEM for the number of determinations shown in the parenthesis. ${ }^{* *} \mathrm{p}<0.01$, compared with Sham; $\# \mathrm{p}<0.05$, compared with Hemorrhage.

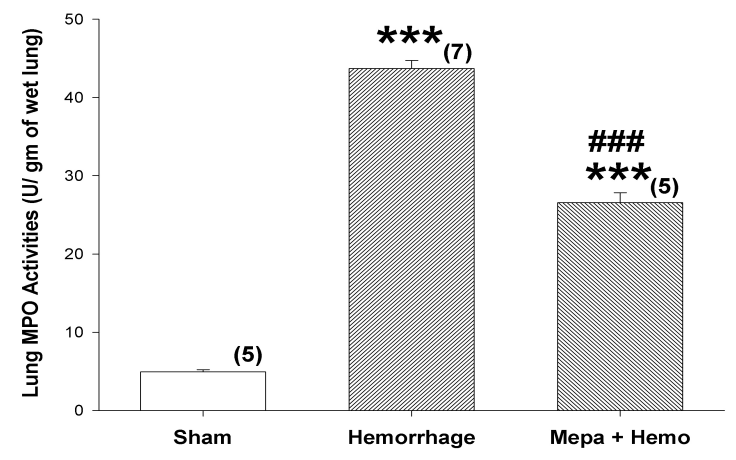

Fig. 2. Rats subjected to severe hemorrhage had significantly increased lung tissue myeloperoxidase (MPO) activities. This change was significantly attenuated by the pretreatment of mepacrine (Mepa+Hemo). The data shown are means \pm SEM for the number of determinations shown in the parenthesis. ${ }^{* * *} \mathrm{p}<0.001$, compared with Sham; $\# \#$ \# $<0.001$, compared with Hemorrhage.

Effect of hemorrhage on serum protein and ferritin levels

Hemorrhage significantly decreased serum protein concentrations compared with sham. Sham rats did not show any changes in serum protein concentration (Fig. 3). Before hemorrhage, all groups had the same serum ferritin levels (Fig. 4). Following hemorrhage, serum ferritin levels of untreated hemorrhaged rats progressively increased from their baseline levels. The values at 60 and 90 minutes showed sharp increases and significantly higher than those of sham and mepacrine-treated rats. Ferritin level at 120 minute was about 3.5 times the baseline level. By comparison, the serum ferritin levels of sham treated rats remained at their baseline levels throughout the $120 \mathrm{~min}$ observation period. Mepacrine treatment attenuated serum ferritin increase in rats subjected

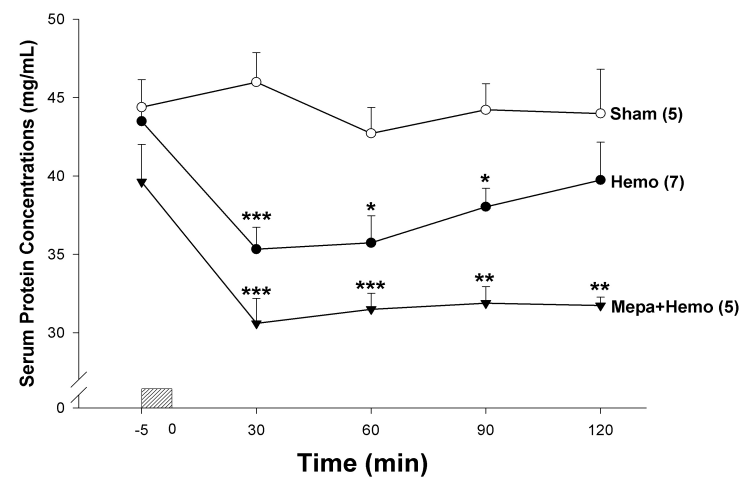

Fig. 3. Following hemorrhage, serum protein concentrations were greatly decreased in both hemorrhaged rats. Serum protein concentrations of sham rats did not change through the experiment. Hashed bar means the period of hemorrhage. Each point represents means \pm SEM for the number of determinations shown in the parenthesis. ${ }^{*} \mathrm{p}<0.05,{ }^{* *} \mathrm{p}<0.01,{ }^{* * *} \mathrm{p}<0.001$, compared with Sham.

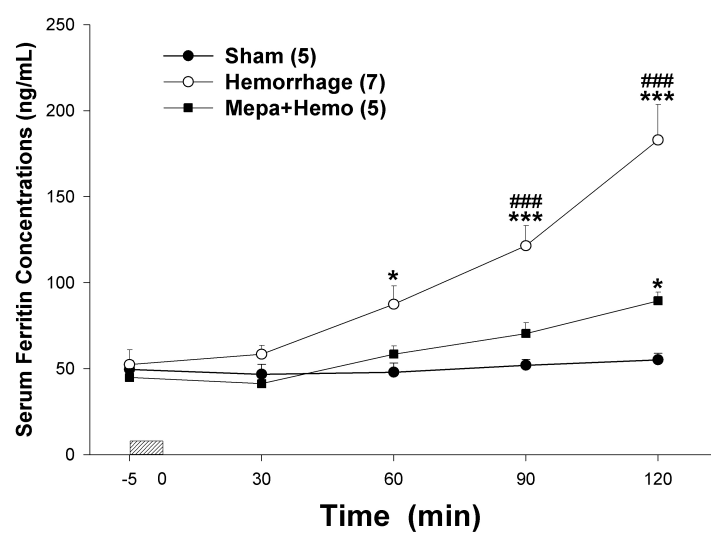

Fig. 4. Rats subjected to hemorrhage had greatly increased serum ferritin concentrations after 60 minutes following hemorrhage. By comparison, mepacrine pretreatment (Mepa+Hemo) significantly attenuated the increase following hemorrhage. Serum ferritin concentrations of Sham rats did not change through the observation period. Hashed bar means the period of hemorrhage. Each point represents means \pm SEM for the number of determinations shown in the parenthesis. ${ }^{*} \mathrm{p}<0.05$, *** $\mathrm{p}<0.001$, compared with Sham; \#\#\#p<0.001, compared with Mepa+Hemo.

to severe hemorrhage.

\section{Effect of hemorrhage on serum $\mathrm{HO}^{-1}$ levels}

Serum HO-1 concentrations of all rats did not change until $60 \mathrm{~min}$ after hemorrhage. However, untreated hemorrhaged rats had slightly increased HO-1 levels at $90 \mathrm{~min}$ and greatly elevated $2 \mathrm{hr}$ after hemorrhage. Sham and mepacrine-treated rats had the same serum HO-1 concentrations and the levels 


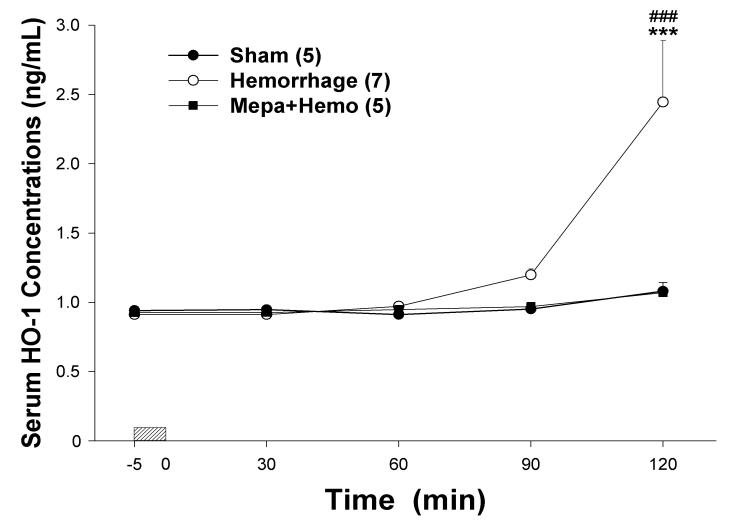

Fig. 5. Serum heme oxygenase-1 (HO-1) concentrations of Sham rats did not change through the observation period. In contrast, rats subjected to hemorrhage had greatly increased serum ferritin concentrations after 60 minutes following hemorrhage. By comparison, mepacrine pretreatment (Mepa+Hemo) significantly attenuated the increase following hemorrhage. Each point is means \pm SEM for the number of determinations shown in the parenthesis. ${ }^{* * *} \mathrm{p}<0.001$, compared with Sham; \#\#\#p<0.001, compared with Mepa+Hemo.

were not changed until the end of experiment (Fig. 5).

Immunohistochemistry for ferritin and $\mathrm{HO}^{-1}$ in $\mathrm{BAL}$ leukocytes

Lung lavage cell immunochemical staining for ferritin showed same pattern of above results. Hemorrhaged rats had greatly increased BAL leukocyte number (Fig. 6C) compared with sham rats (Fig. 6A). Mepacrine treatment also reduced leukocyte number (Fig. 6E). Ferritin staining was only remarkable after hemorrhage (Fig. 6C). Intense immunochemical staining of ferritin was found and localized in the cytoplasm of leukocytes after hemorrhage (Fig. 6D). Lung lavage leukocyte HO-1 expression was also increased in the rats with untreated hemorrhage (Fig. 7C,D) compared with the expression of sham rats (Fig. 7A,B). Mepacrinetreatment decreased the expression of HO-1 (Fig. 7E,F). HO-1 expression was also localized in the cytosol (Fig. 7G).

\section{Discussion}

Oxidative stress is implicated in the pathogenesis of many diseases associated with inflammation such as ARDS, pulmonary fibrosis, and asthma [37]. Trauma and hemorrhagic shock are two of the most common causes of ALI in patients $[15,32]$. As shown in the previous reports [28-30], lungs of rats subjected to severe hemorrhage rapidly develop ALI, which is characterized by an increased influx of leukocytes and increased BAL protein concentrations - findings that resemble changes that occur in the lungs of human subjects who have ALI [32]. Hemorrhagic shock should be considered as "whole-body ischemia" [20], therefore, severe hemorrhage is a good system for studying the effects of a sys-

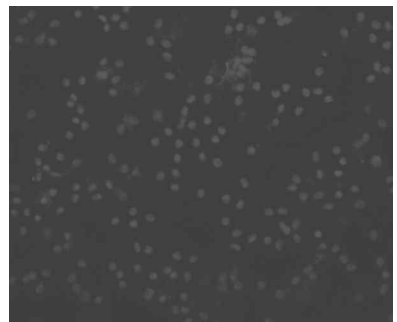

A. Sham $(X 200)$

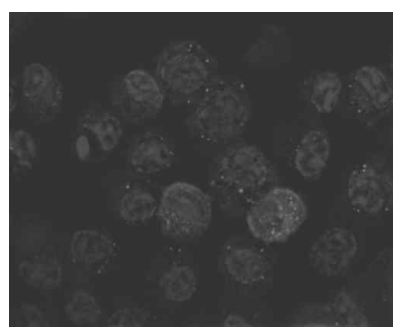

D. Hemorrhage $(X 1,000)$

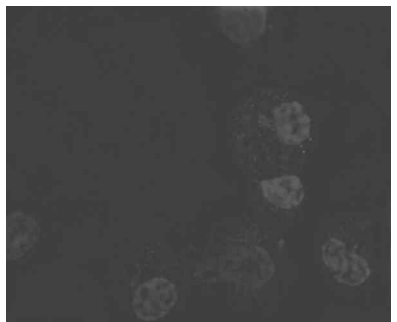

B. Sham $(X 1,000)$

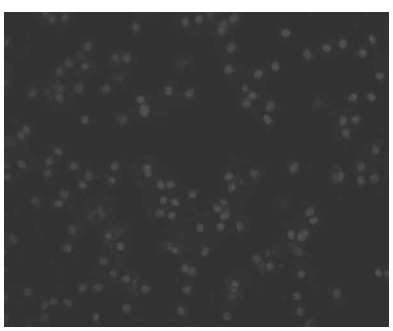

E. Mepa+Hemo (X200)

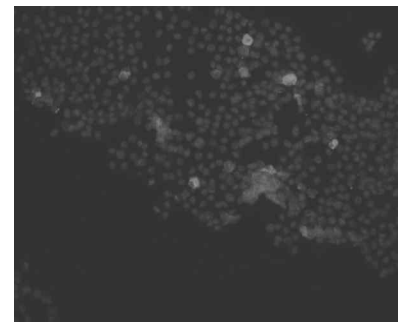

C. Hemorrhage (X200)

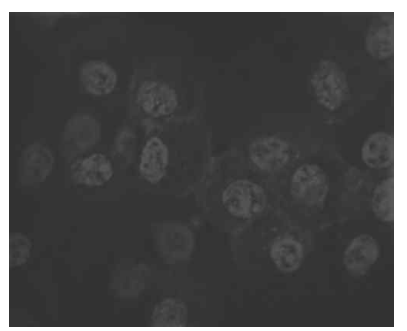

F. Mepa+Hemo $(\mathrm{X} 1,000)$

Fig. 6. Immunohistochemical studies of ferritin in BAL cells $2 \mathrm{~h}$ after hemorrhage. Hemorrhaged rats (C) had increased lung lavage cell number and ferritin expression compared with sham rats (A). Mepacrine treatment (E) attenuated this response following hemorrhage. Ferritin staining was found in the cytoplasm of lung lavage leukocytes following hemorrhage (D) but not in those of sham (B) and mepacrine-treated hemorrhage (F). Original magnifications are shown in the parenthesis. 


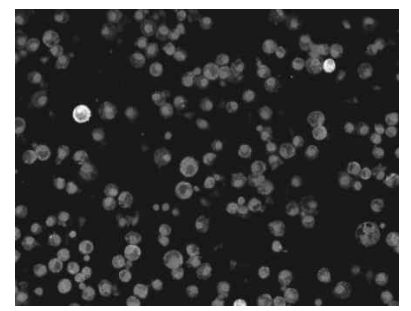

A. Sham $(X 200)$

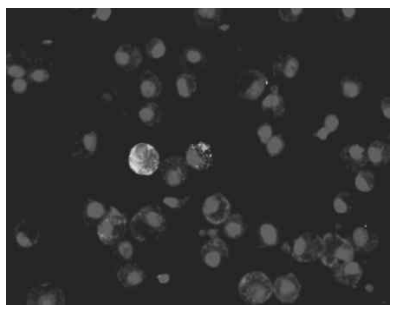

B. Sham $(X 400)$

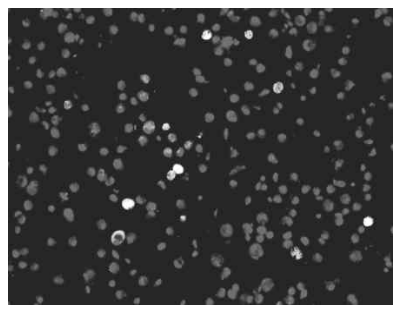

C. Hemorrhage (X200)

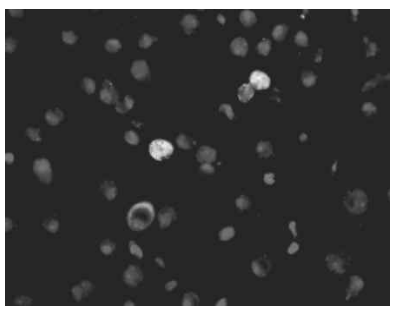

D. Hemorrhage (X400)

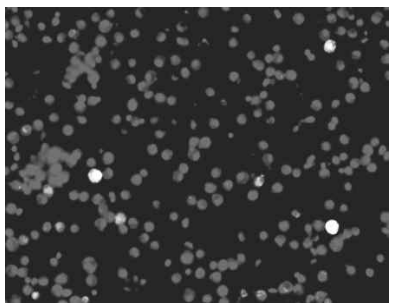

E. Mepa+Hemo (X200)

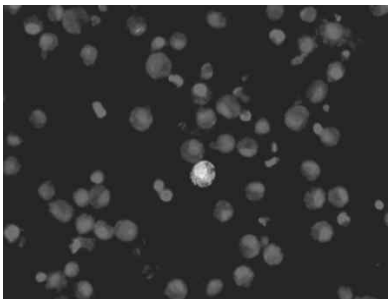

F. Mepa+Hemo $(X 400)$

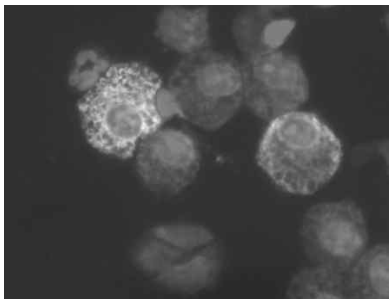

G. $(X 400)$

Fig. 7. Immunohistochemical studies of heme oxygenase-1 (HO-1) in BAL cells $2 \mathrm{~h}$ after hemorrhage. Lung lavage leukocytes expression of HO-1 was increased in the rats subjected to hemorrhage $(\mathrm{C})$ compared to that of sham rats (A). Mepacrine-treated rats had decreased expression of HO-1 (E). HO-1 staining was limited in the cytoplasm of leukocytes (G). Original magnifications are shown in the parenthesis.

temic ischemia-reperfusion insult that leads to ALI. Moreover, this approach may be different in mechanism from more direct lung insults that lead to ALI, such as pneumonia and aspiration.

Ferritins are mainly cytosolic proteins and keep the stored iron separated from the nucleus and other organelles. However, a minor proportion of ferritin in vertebrates is present also in serum and secretory fluids. Serum ferritin is a clinically important index of body iron stores, but its functional role remains largely obscure [1]. Induction of the synthesis of ferritin is an important mechanism for the sequestration of reactive iron and defense against oxidant injury $[2,3]$.

In the present investigation, hemorrhaged rats had increased serum ferritin concentrations despite of the hemodilution. Serum protein concentration decreases most likely occurred as a result of physiological regulation caused by the release of fluid into blood vessels following hemorrhage [39]. In addition, ferritin expression in BAL leukocytes is also significantly elevated following hemorrhage. Mepacrine- treatment attenuated the increase of serum and BAL cell ferritin levels as well as successfully prevented ALI. These findings confirm previous works including in vitro [2] and in vivo [28-30]. Park et al. [28] reported that BAL ferritin levels are closely related with lung lavage protein concentration rather than serum ferritin concentration. They suggested a hypothesis that the increase of serum and BAL ferri- tin might have different origin, and BAL ferritin should be actively secreted and/or released from damaged lung tissues. Present immunohistochemical results might be the answer: BAL fluid leukocyte number and ferritin expression are also increased following hemorrhage, but tissue immunohistochemical staining did not show differences among the groups (data not shown). It suggests that increased BAL ferritinis originated mainly from inflammatory leukocytes rather than the tissue expression following hemorrhage. In addition, the expression of ferritinis in the cytoplasm of lung lavage leukocytes (mainly monocyte/macrophage) after hemorrhage.

In many respects, ferritin can be viewed as a member of the group of proteins that respond to stress and inflammation. Inflammatory cytokines upregulate ferritin synthesis in various mammalian cells, including mesenchimal cells, hepatocytes, and monocyte-macrophages [21].

In addition to the previous results, this study also shows the parallel increases of ferritin levels and ALI in untreated hemorrhaged rats, and the ability of mepacrine to inhibit both ferritin increase and ALI. These findings can suggest a possibility to use serum and/or BAL ferritin levels as a useful biomarker for predicting ARDS.

$\mathrm{HO}$ is a heme-cleaving enzyme that opens the porphyrin ring, producing biliverdin, carbon monoxide (CO), and free iron $[25,36]$. Free iron $\left(\mathrm{Fe}^{2+}\right)$ induces the expression of ferritin, which binds and stores iron in a form less harmful to 
oxidative injury [2]. It is known that HO-1 induction responds to common causes of oxidative stress to the airways, including hyperoxia, hypoxia, endotoxemia, heavy metal exposure, bleomycin, diesel exhaust particles, and allergen exposure $[16,18]$. Therefore, HO not only acts in iron conservation but may protect against oxidative injury by sequestration of free iron and by producing bilirubin, which also has antioxidant properties [35].

In accordance with the above reports, serum HO-1 levels greatly elevated only in hemorrhaged rats as serum ferritin concentrations did. In immunohistochemical study, lung lavage cell HO-1 expression was more prominent in untreated hemorrhaged rats than those of sham and mepacrine-treated hemorrhaged rats. Indeed, HO-1 expression occurs in respiratory epithelial cells, fibroblasts, endothelial cells, and largely in alveolar macrophages [16,18]. Mumby et al. [24] also reported that HO-1 and ferritin were elevated in lungs of ARDS patients. The exact mechanisms to induce cellular expressions of ferritin and HO-1 in this animal model of ALI are not clear at present. Additional studies may be required to explain the exact mechanism of the induction of HO-1 and ferritin in serum and inflammatory cells.

Still there is a remaining question. Expression of ferritin was originally reported to be the mechanism by which HO-1 conferred resistance to oxidative stress in endothelial cells [2]. If this is true in a strict way, BAL fluid cellular expression of HO-1 should be greater than ferritin responses. Several studies have shown that ferritin sometimes appears to substitute for HO-1 action and other times does not. In general, hypoxia increases intracellular generation of reactive oxygen species, and oxidative stress has been shown to mobilize iron from intracellular ferritin, increasing cell content of unbound iron and thereby promoting additional ferritin synthesis [4,6]. Rogers et al. [33] also reported that inflammatory induction of ferritin synthesis was different from iron-dependent ferritin gene expression. Additionally, the potent cellular protection provided by HO-1 induction in rats subjected to endotoxic shock appeared to be ferritin independent and iron dosing was ineffective at conferring protection [26].

Based on these results, therefore, BAL ferritin responses thought to be independent of the HO-1 inductions under these conditions. HO-1 expression may be greatly induced by heme-induced oxidative stress or in the conditions of normal heme and/or hemoglobin levels. However, in this experiment, anemia by severe hemorrhage can be a possible cause of reduced HO-1 induction. Although there is no supporting data for explanation, serum HO-1 and ferritin concentrations may be useful candidate for predicting biomarkers for ARDS in the hemorrhage-induced ALI. In addition, change of serum ferritin is faster than HO-1 in this model of ALI and might be more useful to predict patients at high-risk of progression to ARDS. While this report relates to relatively acute responses, other factors, such as chronic inflammation or iron retention that alter ferritin and other iron binding proteins may also be contributory to ALI.

\section{Acknowledgement}

This work was supported by the grant of Research Institute of Medical Science, Catholic University of Daegu (2007).

\section{References}

1. Arosio, P. and S. Levi. 2002. Ferritin, iron homeostasis, and oxidative damage. Free Rad Biol. Med 33, 457-463.

2. Balla, G., H. S. Jacob, J. Balla, M. Rosenberg, K. Nath, F. Apple, J. W. Eaton, and G. M. Vercellotti. 1992. Ferritin: a cytoprotective antioxidant stratagem of endothelium. J. Biol. Chem 267, 18148-18153.

3. Balla, J., K. A. Nath, G. Balla, M. B. Juckett, H. S. Jacob, and G. M. Vercellotti. 1995. Endothelial cell heme oxygenase and ferritin induction in rat lung by hemoglobin in vivo. Am J. Physiol. 268, L321-L327.

4. Cairo, G., L. Tacchini, G. Pogliaghi, E. Anzon, A. Tomasi, and A. Bernelli-Zazzera. 1995. Induction of ferritin synthesis by oxidative stress. Transcriptional and post-transcriptional regulation by expansion of the "free" iron pool. J. Biol. Chem 270, 700-703.

5. Chabot, F., J. A. Mitchell, J. M. C. Gutteridge, and T. W. Evans. 1998. Reactive oxygen species in acute lung injury. Eur. Respir. J. 11, 745-757.

6. Chandel, N. S., W. C. Trzyna, D. S. McClintock, and P. T. Schumacker. 2000. Role of oxidants in NF-kappa B activation and TNF-alpha gene transcription induced by hypoxia and endotoxin. J. Immunol. 165, 1013-1021.

7. Choi, A. M. and J. Alam. 1996. Heme oxygenase-1: Function, regulation, and implication of a novel stress-inducible protein in oxidant-induced lung injury. Am J. Respir. Cell Mol. Biol. 15, 9-19.

8. Connelly, K. G. and J. E. Repine. 1997. Markers for predicting the development of acute respiratory distress syndrome. Annu. Rev. Med 48, 429-445.

9. Connelly, K. G., M. Moss, P. E. Parsons, E. E. Moore, F. A. Moore, P. C. Giclas, P. A. Seligman, and J. E. Repine. 1997. Serum ferritin as a predictor of the acute respiratory distress syndrome. Am J. Respir. Crit. Care Med 155, 21-25. 
10. Epsztejn, S., H. Glickstein, V. Picard, I. N. Slotki, W. Breuer, C. Beaumont, and Z. I. Cabantchik. 1999. H-ferritin subunit overexpression in erythroid cells reduces the oxidative stress response and induces multidrug resistance properties. Blood 94, 3593-3603.

11. Garner, B., K. Roberg, and U. T. Brunk. 1998. Endogenous ferritin protects cells with iron-laden lysosomes against oxidative stress. Free Radic. Res. 29, 103-114.

12. Ghio, A. J., J. D. Carter, J. H. Richards, L. D. Richer, C. K. Grissom, and M. R. Elstad. 2003. Iron and iron-related proteins in the lower respiratory tract of patients with acute respiratory distress syndrome. Crit. Care Med 31, 395-400.

13. Gutteridge, J. M. C., G. J. Quinlan, S. Mumby, A. Heath, and T. W. Evans. 1994. Primary plasma antioxidants in adult respiratory distress syndrome patients: Changes in iron-oxidizing, iron-binding, and free radical-scavenging proteins. J. Lab. Clin. Med 124, 263-273.

14. Gutteridge, J. M. C., S. Mumby, G. J. Quinlan, K. F. Chung, and T. W. Evans. 1996. Pro-oxidant iron is present in human pulmonary epithelial lining fluid: implications for oxidative stress in the lung. Biochem Biophys. Res. Commun. 220, 1024-1027.

15. Hudson, L. D., J. A. Milberg, D. Anardi, and R. J. Maunder. 1995. Clinical risks for the development of the acute respiratory distress syndrome. Am J. Respir. Crit. Care Med 151, 293-301.

16. Lee, P. J., S. L. Camhi, B. Y. Chin, J. Alam, and A. M. Choi. 2000. AP-1 and STAT mediate hyperoxia-induced gene transcription of heme oxygenase-1. Am J. Physiol. 279, L175-L182.

17. Lee, Y. M., B. M. Hybertson, H. G. Cho, L. S. Terada, O. Cho, A. J. Repine, and J. E. Repine. 2000. Platelet-activating factor contributes to acute lung leak in rats given interleukin-1 intratracheally. Am J. Physiol. 279, L75-L80.

18. Li, N., M. I. Venkatesan, A. Miguel, R. Kaplan, C. Gujuluva, J. Alam, and A. Nel. 2000. Induction of heme oxygenase-1 expression in macrophages by diesel exhaust particle chemicals and quinones via the antioxidant-responsive element. Immunol. 165, 3393-3401.

19. Louie, S., B. Halliwell, and C. E. Cross. 1997. Adult respiratory distress syndrome: a radical perspective. $A d V$. Pharmacol. 38, 457-490.

20. McCord, J. M. 1985. Oxygen-derived free radicals in post-ischemic tissue injury. N. Engl. J. Med 312, 159-163.

21. Miller, L. L., S. C. Miller, S. V. Torti, Y. Tsuji, and F. M. Torti. 1991. Iron-independent induction of ferritin $\mathrm{H}$ chain by tumor necrosis factor. Proc. Natl. Acad Sci. USA 88, 4946-4950.

22. Morris, C. J., J. R. Earl, C. W. Trenam, and D. R. Blake. 1995. Reactive oxygen species and iron-a dangerous partnership in inflammation. Int. J. Biochem Cell Biol. 27, 109-122.

23. Morse, D. and A. M. Choi. 2002. Heme oxygenase-1: the "emerging molecule" has arrived. Am J. Respir. Cell Mol. Biol. 27, 8-16.

24. Mumby, S., R. L. Upton, Y. Chen, S. J. Stanford, G. J.
Quinlan, A. G. Nicholson, J. M. Gutteridge, N. J. Lamb, and T. W. Evans. 2004. Lung heme oxygenase-1 is elevated in acute respiratory distress syndrome. Crit. Care Med 32, 1130-1135.

25. Otterbein, L. E., M. P. Soares, K. Yamashita, and F. H. Bach. 2003. Heme oxygenase-1: unleashing the protective properties of heme. Trends Immunol. 24, 449-455.

26. Otterbein, L., B. Y. Chin, S. L. Otterbein, V. C. Lowe, H. E. Fessler, and A. M. Choi. 1997. Mechanism of hemoglobin-induced protection against endotoxemia in rats: a ferritin-independent pathway. Am J. Physiol. 272, L268-L275.

27. Park, S. D. and Y.-Y. Park. 2006. Changes of serum ferritin in acute lung injury induced by intestinal ischemia/ reperfusion. Korean J. Physiol. Pharmacol. 10, 187-191.

28. Park, Y.-Y., B. M. Hybertson, R. M. Wright, M. A. Fini, N. D. Elkins, and J. E. Repine. 2004. Serum ferritin elevation and acute lung injury in rats subjected to hemorrhage: Reduction by mepacrine treatment. Exp. Lung Res. 30, 571-584.

29. Park, Y.-Y. and Y. M. Lee. 2006. Effects of aspirin on the pathogenesis of acute lung injury in rats subjected to hemorrhage. Tuberc. Respir. Dis. 60, 83-91.

30. Park, Y.-Y., B. M. Hybertson, R. M. Wright, and J. E. Repine. 2003. Serum ferritin increases in hemorrhaged rats that develop acute lung injury: effect of an iron-deficient diet. Inflammation 27, 257-263.

31. Quinlan, G. J., T. W. Evans, and J. M. Gutteridge. 2002. Iron and the redox status of the lungs. Free Radic. Biol. Med 33, 1306-1313.

32. Repine, J. E. 1992. Scientific perspectives on adult respiratory distress syndrome. Lancet 339, 466-469.

33. Rogers, J. T., K. R. Bridges, G. P. Durmowicz, J. Glass, P. E. Auron, and H. N. Munro. 1990. Translational control during the acute phase response. Ferritin synthesis in response to interleukin-1. J. Biol. Chem 265, 14572-14578.

34. Sharkey, R. A., S. C. Donnelly, K. G. Connelly, C. E. Robertson, C. Haslett, and J. E. Repine. 1999. Initial serum ferritin levels in patients with multiple trauma and the subsequent development of acute respiratory distress syndrome. Am J. Respir. Crit. Care Med 159, 1506-1509.

35. Stocker, R., Y. Yamamoto, A. F. McDonagh, A. N. Glazer, and B. N. Ames. 1987. Bilirubin is an antioxidant of possible physiological importance. Science 235, 1043-1046.

36. Tenhunen, R., H. S. Marver, and R. Schmid R. 1968. The enzymatic conversion of heme to bilirubin by microsomal heme oxygenase. Proc. Natl. Acad Sci. USA 61, 748-755.

37. Terry, C. M., J. A. Clikeman, J. R. Hoidal, and K. S. Callahan. 1999. TNF- $\alpha$ and IL-1 $\alpha$ induce heme oxygenase-1 via protein kinase $\mathrm{C}, \mathrm{Ca} 2+$, and phospholipase $\mathrm{A} 2$ in endothelial cells. Am J. Physiol. 276, H1493-H1501.

38. Willis, D., A. R. Moore, R. Frederick, and D. A. Willoughby. 1996. Heme oxygenase: a novel target for the modulation of the inflammatory response. Nat. Med 2, 87-90.

39. Zweifach, B. W. 1974. Mechanisms of blood flow and fluid exchange in microvessels: hemorrhagic hypotension model. Anesthesiology 41, 157-168. 
초록 : 출혈로 인한 폐 염증세포에서의 ferritin과 heme oxygenase-1의 발현

\section{권정완 · 박윤엽*}

(대구가톨릭대학교 의과대학 생리학교실)

급성 폐손상과 급성 호흡곤란 증후군은 치사율이 매우 높은 질환임에도 불구하고 현재까지 뚜렷한 치료법이 확립되지 않아서 조기진단에 많은 관심을 기울이고 있다. 본 실험에서는 출혈성 쇼크로 유발되는 급성 폐손상 모델에서 철대사를 조절하는 인자로 알려진 heme oxygenase-1 (HO-1)과 ferritin의 변화 양상을 알아보고 급성 폐손상 또는 급성 호흡곤란 증후군의 조기진단인자로서 적합한지를 알아보고자 하였다. 실험동물은 체중 300-450 $\mathrm{g}$ 의 Sprague-Dawley rat을 사용하였으며, 급성폐손상과 ferritin 및 HO-1 변화의 관계를 알아보기 위하여 정상군 (Sham), 출혈군 및 phospholipase $\mathrm{A}_{2}$ 억제제인 mepacrine $(60 \mathrm{mg} / \mathrm{kg}, \mathrm{iv})$ 을 전처치한 출혈군으로 나누어 실험하였 다. Sham 군은 출혈군과 동일하게 수술하고 출혈은 시키지 않았으며 나머지 과정은 출혈군과 동일하게 처리하였다. 출혈은 withdrawal pump를 이용하여 분당 $4 \mathrm{ml} / \mathrm{kg}$ 의 속도로 5 분간 총 체중 $\mathrm{kg}$ 당 $20 \mathrm{ml}$ 의 혈액을 대퇴동맥에 연결한 관을 통하여 출혈시켰다. 출혈로 인하여 급성 폐손상이 유발되었으며 이는 mepacrine 전처치로 유의하게 억제되었다. 출혈 후 혈장 단백질 농도는 감소하였으나 혈장 ferritin 농도는 출혈 60분 후부터, HO-1 농도는 90분 후 부터 증가하여 2시간 후에는 Sham 군에 비해 크게 증가하였으며, 이는 mepacrine 전 처치한 경우에서 유의하게 둔화되었다. 폐세척액 내의 세포에서 ferritin과 HO-1의 발현량은 출혈군에서 가장 크게 나타났고, mepacrine을 전 처치한 출혈군에서 발현량이 줄어들었다. 이상의 결과로 살펴볼 때, 혈장 ferritin 및 HO-1은 출혈성 쇼크로 유발되는 급성 폐손상의 정도와 밀접한 상관관계를 가지고, 비록 정도의 차이는 있더라도 폐세척액 내의 염증성 세포에서도 발현량이 증가하는 것을 관찰할 수 있었다. 그러므로, 혈장의 ferritin 및 HO-1 농도를 급성 폐손상 및 급성 호흡곤란 증후군의 조기진단을 위한 간접적인 생체지표로 사용할 수 있을 것으로 보이며, 이 실험모델에서 는 ferritin이 HO-1보다 더 예민한 인자로 평가된다. 